\title{
Strategic Management of Higher Education Institutions
}

\begin{abstract}
The main goal of this paper is to identify and discuss some basic principles of strategy-making in a modern university in the customer-driven education context, and to stimulate further discussion on this topic. The study aims at providing an in-depth analysis of the internal factors, which comprise a complicated educational environment of a higher education institution. It is argued that in their labours to develop and implement a number of strategies, education managers should distinguish between the corporate-level strategic goals and functional area-specific strategic goals that are related to the university's strategic areas of development and research.
\end{abstract}

Keywords: higher education institution, education manager, strategic management.

Pagrindinis šio straipsnio tikslas - nustatyti ir aptarti pagrindinius modernaus universiteto strategijos formavimo principus švietimo, orientuoto ị vartotojų poreikius, kontekste bei skatinti tolesnes diskusijas šia tema. Tyrimo tikslas - atlikti išsamią vidinių veiksnių, kurie sukuria sudètingą mokomąją aplinką aukštojo mokslo institucijoje, analizę. Teigiama, jog reikia kurti ir igyvendinti keletą strategijų, švietimo vadovai turi atskirti korporatyvinio lygio strateginius tikslus nuo funkcinių, konkrečių sričių, strateginių tikslų, kurie susiję su universiteto strateginių sričių plètra ir moksliniais tyrimais.

Raktiniai žodžiai: aukštojo mokslo institucija, švietimo vadovas, strateginis valdymas.

\section{Introduction}

Nowadays European higher education institutions (HEIs) are functioning in the extremely competitive international environment; the knowledge-based society poses significant challenges to modern universities in various aspects: managerial, academic, technological, economic, etc. (see Stukalina, 2010/1). Higher education is now "at the heart of the Europe
2020 Strategy and of Europe's ambition to become a smart, sustainable and inclusive economy"; it plays a central role in individual and societal progress; it influences innovation and research and "provides the highly skilled human capital that knowledge-based economies need to generate growth and prosperity" (COM(2013) 499 final). The new generations of learners, technological innovations, budgetary constraints, and economic factors have 
given rise to the need for re-evaluating strategies employed in higher education (Kazeroony, 2012). Besides, increased competition between higher education institutions in terms of attracting and keeping students also makes education managers reconsider their strategy aimed at identifying the elements and indicators of competitive advantage. According to D. Watson (2000), managing strategy is vital for a university, as it provides the realization of its core activities.

Strategic management theories provide a basis for novel approaches to strategy development in higher education institutions. However, they do not address all pressing issues that education managers face today. Modern universities are sophisticated multi-level organizations, and the complex pattern of various contributory factors forms the background of educational management. Developing their strategy education managers must also consider specific organisational characteristics of this sector (Tavernier, 2005). Therefore, there is a need for a thorough analysis of both traditional approaches and innovative attitudes that can be used by education managers in the context of strategy-making.

The main goal of this paper is to identify and discuss some basic principles of strategy-making in a contemporary university in the customer-driven education context, and to stimulate further discussion on this topic. The study aims at providing an in-depth analysis of the internal factors, which comprise a complicated educational environment of a higher education institution. It is argued that in their labours to develop and implement a number of strategies, education managers should distinguish between the corporatelevel strategic goals and functional area- specific strategic goals, which are related to the university's strategic areas of development and research.

The analysis provided in this paper is based on the academic literature review dedicated to strategy-making as a central function of contemporary management. The analysis reported in the paper is also based upon the author's professional experience in the area of educational management.

\section{Research results and discussion}

\section{Academic literature review}

The academic literature review related to strategic management shows that creating an effective strategy aimed at organizational development is one of the primary tasks of modern managers. Strategy-making is concerned with formulating and applying strategies for promoting a "superior alignment between the organization and its environment and the achieving of strategic goals" (Griffin, 1990). The focus of strategic management is on the longer-term survival and development of an organization (Stoner, 1978). According to A. Henry (2008), an effective strategy allows managers to employ the available resources and capabilities of an organization in order to "exploit opportunities and limit threats in the external environment". As stated by A. A. Thompson and A. J. Strickland (2003), powerful execution of a powerful strategy is regarded as a formula for success in business. As said by P. Tabatoni and A. Barblan (2002), the main target of strategic management is to lead people involved in the development of the organisation and help them concentrate on the organisation's image, 
question its position in a new environment and ensure its ongoing growth. Strategic management provides the frame for decisions about customers and products, various resources including financial assets, organizational systems and technologies, risk, etc. (Morden, 2007).

H. Koontz and H. Weihrich (2010) define strategy as determination the main long-term goals of an organization and the implementation of sequences of actions and distribution of resources that are necessary to accomplish these objectives. Through these actions an organization creates and employs resources necessary to deliver services (products) that customers find valuable (Haberber, Rieple, 2008). Strategy is related to understanding of both the external environment and the internal resources of an organization (Capon, 2008). Since management occurs concurrently in different organizational contexts and managers must make their decisions in various situations, the holistic approach to managing the integrated organizational resources is supposed to be an efficient approach to cope with the most significant issues related to strategy formation (Stukalina, 2013). The task of creating a strategy begins with thorough examination of the organization's internal and external situation (Thompson, Strickland, 2003). Strategy involves the whole organization (Bush, Coleman, 2000); it involves the investigation of the major initiatives taken by an organization's senior management in the best interests of its owners (Nag et al., 2007). Consequently, it requires appropriate planning and setting clear and achievable objectives. Strategic objectives, being related to a company's competitive situation, are based on an analysis of the current market situation and opportunities (Kotler, 2000).
According to J. Huisman and A. Pausits (2010), the sustainability of higher education reforms are supposed to be directly related to the level of professionalism of higher education management that has to behave proactively and entrepreneurially. As said by D. Watson (2000), managing strategy is supposed to be the most important thing a university does; it allows all of its main activities (teaching, research, social and economic service) to be realised. Today, the relevance of strategic management to HEIs is likely to increase as the size of public higher education relative to the private not-for-profit and forprofit sectors is decreasing in most parts of the world; besides, public universities are forced to generate revenue from nongovernment sources (Eastman, 2003). Strategic management in a higher education institution can be characterized as forward-thinking leading towards those institutional policies that aims for increasing the university's potential for change, a constant concern for quality along with propagation of evaluation methods and quality standards being at the heart of education managers' activities (Tabatoni, 2002). One also should bear in mind that, in higher education, strategic management must be developed with a "keen eye on the specific organisational characteristics of that sector" (Tavernier, 2005); educational management has to be with the purpose or aims of education (Bush, 2007). Strategic planning is a necessity in higher education, as universities "educate the most talented people who are best to secure the future of the next generation" (Kettunen, 2011).

As stated by P. Tabatoni and A. Barblan (2002), strategic planning in a HEI embraces all essential elements, which are central to any managerial process, such 
as goals, norms, resources, organizational structures, relationships within the organization, etc. In education, strategy formation aimed at school development involves evaluation of the internal resources of an academic institution, the external impacts and acknowledgement of the dominant internal culture (Fiddler, 2002), the encouragement of university cultures supportive of strategic quality efforts being a precondition of effective quality operations (Davies, 2002).

European higher education is now in a state of constant transformation (COM (2003) 58 final) as well; the pressures for modernizing higher education are apparent everywhere, and the pace of change is growing (McRoy, Gibbs, 2009). Contemporary universities must prepare their graduates for the complex and changing demands of the challenging global labour market. In addition, the expectations of students are changing: students more and more expect to choose "what they learn, how they learn and when they learn, according to their individual needs and interests" (COM(2013) 499 final). So, as stated by H. Kazeroony (2012), modern HEIs must not disregard the changing nature of learners. Since the Bologna Process was launched (Bologna Declaration, 1999), improving quality of higher education and developing quality assurance systems linked to establishing stakeholder confidence has been a high priority for EU countries (The European Higher Education Area in 2012: Bologna Process Implementation Report, 2012). As stated in Standards and Guidelines for Quality Assurance in the European Higher Education Area (2005), European universities must develop a policy and the related procedures for the assurance of the quality and standards of their programmes and awards; they should create and implement a strategy for the continuous enhancement of quality that must have a formal status and should also include a role for students and other stakeholders.

According to L. Moldovan (2012), competitive strategies in the area of higher education can be developed through quality. By means of integration of quality assurance and strategic management procedures, the university's strategy is implemented and organizational objectives are achieved (Kettunen, 2011). Quality of learning, together with responsiveness to economic needs of graduates (i.e. providing graduates with the necessary competencies), are among the issues that HEIs should carefully investigate in formulating an appropriate strategy (Kazeroony, 2012). The university's strategy may embrace those strategies, which "describe how the university plans to gain advantage over competitors and are differentiated by the nature of guidance in order to ensure the competitiveness of the organization" (Moldovan, 2012). Thus, market-oriented strategic planning in a higher education institution is closely related to monitoring the quality of educational services in the customer-driven education framework. Creating their strategy education managers should take into consideration both external and internal factors having impact on their operation and influencing the choice of actions and methods employed for strategic planning process (see Stukalina, 2013).

\section{Strategic background of educational management in a contemporary university}

According to L. Moldovan (2012), modern universities develop and implement a number of strategies that are distinguished 
by the character of management practices used to guarantee the competitiveness of the educational organization, including strategies focused on a demand of the market in a certain qualification, strategies focused on quality of the study program, etc. These strategies are related to the external (e.g. the market demand) and internal (e.g. quality of study programs) factors that shape the strategic background of educational management in a HEI.

The external factors are associated with the external pressures that determine the manner, in which the internal resources of an educational organisation are managed and allocated in order to support sustainable learning process. The internal factors comprise tangible (non-human), non-tangible (human) and semi-tangible (informational) resources (see Stukalina, 2008). Semi-tangible resources symbolize the intellectual capital embodied in the educational environment; they are stored as documents in both paper and electronic form (in organizational databases). In a broader sense, they represent the intellectual property (the personified intellectual capital) of a university. Therefore, the internal resources of a higher education institution are heterogeneous in nature; they embrace the integrated non-linear multi-level educational environment, which represents an academic community of people - academicians, educational managers and administration, students (see Stukalina, 2010/2).

The overall management of the integrated educational environment occurs at different levels and in various functional areas of a university; it is aimed at accomplishing the organization's synergy necessary for achieving education-specific organizational goals (Figure 1).

In a complicated environment of modern educational organizations, strategymaking is not a task for senior managers only (Thompson, Strickland, 2003). Consequently, one of the basic principles of the HEI management model described above includes managing the educational environment as an integrated multi-level system in a centralized manner, at the same time giving functional areas a certain degree of autonomy in developing and implementing different strategies related to specific organizational domains.

The other key principles may be summarized as follows.

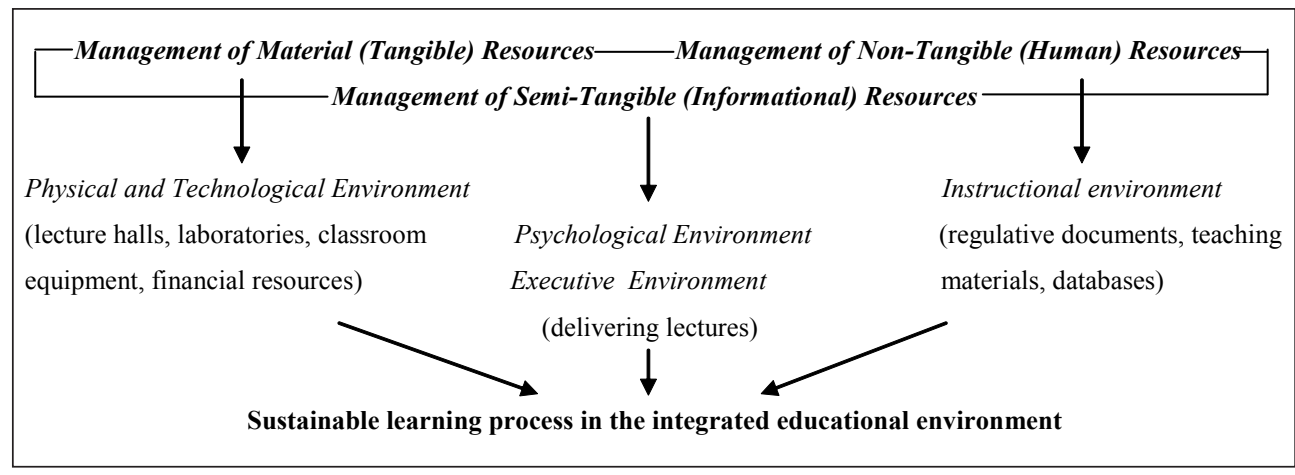

Fig. 1. Management of the non-linear multi-level educational environment of a modern university Source: the author's construction based on Y. Stukalina (2010/2). 
1. Education managers should acknowledge the leading role of the embodied intellectual capital and ensure indirect participation of all university stakeholders (including students as consumers of educational services in the customer-focused context) in strategic decision-making in the framework of quality assurance practices (see Stukalina, 2013).

2. Strategic decisions are made in a variety of circumstances and social situations, and managers operating at different organizational levels may develop various decision models based on their experience in education business.

3. Data required for supporting strategic decision-making are gathered throughout the integrated educational environment in the framework of an organization-wide communication system including different knowledge transfer schemes that embrace basic knowledge processes - knowledge acquisition, knowledge sharing and new knowledge creation.

4. Structured (planned) knowledge transfer schemes support decision-making at the highest level of a university; senior managers may have a variety of decision models based on their experience in education or business (see Stukalina, 2010/3).

5. Strategies in a higher education institution may be initiated at different management levels: a) management of tangible resources; b) management of non-tangible resources; c) management of semi-tangible resources.

\section{Some basic principles of strategy- making in a modern higher education institution}

So it may be reasonable to conclude that strategic management of the integrated educational environment should be approached from a holistic perspective; it embraces a variety of external and internal factors as well as their relationships and interactions. According to A. A. Thompson and A. J. Strickland (2003), in traditional strategic management in business organizations, they distinguish between four levels of strategy-making hierarchy: corporate strategy (an overall managerial action plan), business strategy (a managerial action plan for a single line of business), functional strategy (a managerial action plan for running a functional activity within a business), and operating strategy (a managerial action plan for managing main organizational units). This theory is quite applicable to higher education organizations, though there are grounds to assume that HEIs develop their strategies on account of their specific nature. Compared to business organizations, the goals set by educational institutions are supposed to be rather immaterial, as HEIs focus more on knowledge creation, knowledge sharing and values formation, so many goals are attainable over the years (Hechanova, Cementina-Olpoc, 2013). Besides, academic organizations are also different from traditional business structures in terms of the internal hierarchy, job levels and roles in educational institutions being less differentiated (Ibid.).

With due account for the complicated nature of the educational environment, the following principles of strategy-making are supposed to be used in a modern HEI.

1. Applying the holistic approach to strategic planning: a higher education institution is regarded as a single entity comprising various integrated and interrelated subsystems, the academic strengths of the university being grounded in a wide range 
of organizational resources (tangible, nontangible, semi-tangible); the resources are aimed at accomplishing academic excellence and competitive advantage.

2. Distinguishing between the following goal areas:

1) Corporate-level strategic goals strategic goals that are broad in nature and are associated with the entire educational organization as a single body; they are aimed at achieving competitive advantage.

2) Functional area-specific strategic goals that arise out of the corporate-level goals; they are aimed at creating a constructive educational environment and achieving academic excellence:

- University services and facilities (a combination of tangible, non-tangible and semi-tangible resources)

- Education (a combination of tangible, non-tangible and semi-tangible resources)

- Research (a combination of tangible, non-tangible and semi-tangible resources) resources).

- Academic staff (non-tangible

3. Identifying priority goal areas in order to enhance academic excellence and organizational performance.

4. Supporting each goal area by a set of appropriate strategic initiatives and the related quality assurance procedures that are intended for enhancing educational excellence and competitive advantage.

Corporate-level strategy-making involves all available resources of an educational organization; functional areaspecific strategy-making may involve combinations of resources depending on the nature of a particular domain. The highest overall priority for senior educational management is achieving competitive advantage on the worldwide higher education market that is characterized by increasing competition between public and private higher education institutions to attract international students and academic staff, research funds, etc. In consort with this priority, special emphasis should be also given to stimulating excellence in education and research, improving the quality of university services and facilities, as well as professional development of university academic staff in the context of lifelong learning. The proposed strategic goal areas as well as a few corresponding university-wide strategic initiatives, which may be applied to support strategy-making in a higher education institution and which are aimed at maintaining and enhancing academic excellence and competitive advantage, are described in Table 1.

The realization of the strategic initiatives mentioned above requires the involvement and appropriate distribution (re-distribution) of the available educational environment resources and external funds, as well as the support of education managers, administration, academic and attending staff from all functional entities (colleges, faculties, chairs, departments, etc.), not to speak of university students. Thus, the emphasis should be put on providing tight collaboration throughout the educational environment for achieving necessary synergy across functional units and across disciplinary areas. Besides, assessing progress on the strategic plan goals and strategic initiatives can be viewed as an essential pre-requisite for successful strategic management of a higher education institution (provided that suitable qualitative and quantitative indicators are used for assessing every goal in the longterm action plan). 
Main strategic goal areas and the corresponding supportive strategic initiatives

\begin{tabular}{|c|c|c|c|}
\hline No. & Strategic goal area & Example & $\begin{array}{c}\text { Supportive strategic } \\
\text { initiatives }\end{array}$ \\
\hline 1. & $\begin{array}{l}\text { Corporate-level strate- } \\
\text { gic goals } \\
\text { External focus }\end{array}$ & $\begin{array}{l}\text { Maintain and enhance university overall } \\
\text { excellence in order to be ranked among the } \\
\text { top } 100 \text { world universities } \\
\text { Cooperate with other HEIs, enterprises } \\
\text { and interest groups for achieving aca- } \\
\text { demic (research) excellence and competitive } \\
\text { advantage } \\
\text { Cultivate a constructive and motivating } \\
\text { educational environment aimed at achieving } \\
\text { academic (research) excellence and competi- } \\
\text { tive advantage }\end{array}$ & $\begin{array}{l}\text { Develop an overall long-term } \\
\text { managerial action plan } \\
\text { Create an effective coordina- } \\
\text { tion mechanism in the frame } \\
\text { of an overall action plan } \\
\text { Develop a set of qualitative } \\
\text { and quantitative indicators for } \\
\text { regular educational environ- } \\
\text { ment evaluation }\end{array}$ \\
\hline \multirow{4}{*}{2.} & $\begin{array}{l}\text { Functional area-speci- } \\
\text { fic strategic goals } \\
\text { University services } \\
\text { and facilities }\end{array}$ & $\begin{array}{l}\text { Maintain and further develop well-run serv- } \\
\text { ice structures and supporting infrastructure } \\
\text { necessary for providing sustainable educa- } \\
\text { tional process } \\
\text { Recruit, encourage and retain excellent at- } \\
\text { tending staff for providing sufficient support } \\
\text { to students and teachers }\end{array}$ & $\begin{array}{l}\text { Implement cost-effective } \\
\text { university infrastructure } \\
\text { improvements } \\
\text { Develop and implement } \\
\text { consistent recruitment } \\
\text { procedures in the frame of an } \\
\text { overall action plan }\end{array}$ \\
\hline & Education & $\begin{array}{l}\text { Provide students with a high-quality educa- } \\
\text { tion that will supply university graduates } \\
\text { with a wide range of multidisciplinary skills } \\
\text { required for the knowledge-based economy }\end{array}$ & $\begin{array}{l}\text { Develop and implement a } \\
\text { long-term ICT-supported } \\
\text { education plan in the frame of } \\
\text { an overall action plan }\end{array}$ \\
\hline & Research & $\begin{array}{l}\text { Maintain and enhance excellence in research } \\
\text { and innovation; enhance university research } \\
\text { cooperation with partner HEIs, research } \\
\text { centres and business }\end{array}$ & $\begin{array}{l}\text { Strengthen support for } \\
\text { research grants and collabora- } \\
\text { tion in the frame of interna- } \\
\text { tional research activities }\end{array}$ \\
\hline & Academic staff & $\begin{array}{l}\text { Recruit, encourage and retain first-rate aca- } \\
\text { demics and teachers for enhancing academic } \\
\text { excellence and competitive advantage }\end{array}$ & $\begin{array}{l}\text { Develop and implement } \\
\text { consistent recruitment } \\
\text { procedures in the frame of an } \\
\text { overall action plan }\end{array}$ \\
\hline
\end{tabular}

Source: the author's suggestions based on the academic literature review and her experience in the area of educational management.

For example, it may be done in the form of a wide-ranging evaluation of the integrated educational environment performed in the framework of providing quality assurance in education; it presupposes involving indirect participation 
of the university stakeholders (including students as consumers of educational services) in strategic decision-making, and can be regarded as one of the central quality assurance activities associated with the strategic management for higher school improvement (see Stukalina, 2013). According to Ch. Stråhlman (2012), students' participation in quality assurance procedures helps ensure the legitimacy of the quality assurance system and its results.

\section{Conclusions, proposals, recommendations}

The analysis performed in this paper allows the author to draw a few conclusions. The following points detail a number of recommendations for senior education managers.

1. In the complicated educational environment, characterized by the internal resources integration and collaboration across the organization, managers have to use the holistic approach to creating an inclusive long-term competitive strategy aimed at organizational development; this strategy may include various "substrategies" in the framework of an overall action plan. Multiple strategies have to be initiated at different levels and in various functional units of a higher education institution.

2. In the context of strategy formation in a modern university, education managers ought to consider both external and internal factors, which influence the choice of strategic initiatives employed for continuous HEI improvement. The external pressures (social, political, environmental, etc.) determine the way, in which the internal resources of a university are managed and distributed.

3. In their labours to develop and implement appropriate strategic initiatives, education managers should distinguish between the corporate-level (overall) strategic goals and functional area-specific strategic goals related to the university's strategic areas of development and research: a) university services and facilities, b) education and research, c) academic staff. It is determined by the specific nature of modern higher educational institutions, which are complex multi-level structures.

4. The implementation of strategic initiatives aimed at achieving academic excellence and competitive advantage requires the appropriate distribution (redistribution) of the internal educational environment resources and external funds. In the process, a special emphasis should be put on providing tight collaboration throughout the educational organization for attaining necessary synergy across functional areas. For this purpose, a systematic evaluation of the integrated educational environment might be used in the framework of providing quality assurance in education.

The paper is written with the intention of stimulating further discussion on some basic issues related to the strategic management of modern universities in the customer-driven education context. The author hopes that whatever lessons this analysis provides will be helpful to education managers responsible for developing a strategy for a higher school improvement. 


\section{References}

1. Bush, T. (2007). Educational Leadership and Management: Theory, Policy, and Practice, South African Journal of Education, 27(3), pp. 391-406.

2. Bush, T. \& Coleman, M. (2000). Leadership and Strategic Management in Education. London: SAGE Publications.

3. Bologna Declaration (1999). [Online] Available at: http://www.ond.vlaanderen.be/hogeronderwijs/Bologna/documents/MDC/ BOLOGNA_DECLARATION1.pdf [Accessed 17 September 2013].

4. Capon, C. (2008). Understanding Strategic Management. UK: Pearson Education Limited.

5. COM (2003) 58 final. The Role of the Universities in the Europe of Knowledge. [Online] Available at:http://europa.eu/legislation_summaries/ education_training_youth/lifelong_learning/ c11067_en.htm [Accessed 27 August 2013].

6. $\operatorname{COM(2013)~} 499$ final. European Higher Education in the World, Communication from the Commission to the European Parliament, the Council, the European Economic and Social Committee and the Committee of the Regions. [Online] Available at: http://ec.europa.eu/education/higher-education/doc/com499_en.pdf [Accessed 28 December 2013].

7. Davies, J. (2002). Cultural Change in Universities in the Context of Strategic and Quality initiatives, Thema, 2, European University Association, 12-21. [Online] Available at: http://www.eua.be/ eua/jsp/en/upload/strategic_manag_uni_institutional_devlpt.1069322397877.pdf [Accessed 10 October 2013].

8. Eastman, J. (2003). Strategic Management of Universities? CSSHE Professional File, Fall 2003, pp.1-56. [Online] Available at: http://www.csshe scees.ca/pf/PF_24\%20_Eastman.pdf [Accessed 23 December 2013].

9. Fiddler, B. (2002). Strategic Management for School Development: Leading Your School's Improvement Strategy. London: SAGE Publications.

10. Griffin, R., W. (1990). Management (3rd ed.). Boston: Houghton Muffin Company.

11. Haberberg, A., Rieple, A. (2008). Strategic Management. Theory and Application. New-York: Oxford University Press.

12. Hechanova, R. M., Cementina-Olpoc, R. (2013). Transformational Leadership, Change Management, and Commitment to Change:
A Comparison of Academic and Business Organizations, The Asia-Pacific Education Researcher, 22(1), pp. 11-19. [Online] Available at: http:// link.springer.com/article/10.1007\%2Fs40299-012 -0019-z\#page-1 [Accessed 29 December 2013].

13. Henry, A. (2008). Understanding Strategic Management (2nd ed.). New York: Oxford University Press Inc.

14. Huisman, J., Pausits, A. (eds) (2010). Higher Education Management and Development. Compedium for Managers. New York: Waxmann Publishing Co.

15. Kazeroony, H. (2012). The Strategic Management of Higher Education. Serving Students as Customers for Institutional Growth. USA: Business Expert Press.

16. Kettunen, J. (2011). Strategy and Quality Maps in Higher Education, US-China Education Review, February 2011, 8(2), pp. 149-156. [Online] Available at: http://files.eric.ed.gov/fulltext/ ED519538.pdf [Accessed 22 December 2013].

17. Koontz, H., Weihrich, H. (2010). Essentials of Management. An International Perspective (8th ed.). New Delhi: Tata McGraw Hill.

18. Kotler, Ph. (2000). Marketing Management. New Jersey: Prentice Hall, Upper Saddle River.

19. McRoy, I., Gibbs, P. (2009). Leading Change in Higher Education, Educational Management Administration \&Leadership, 37(5),pp.687-704. http://dx.doi.org/10.1177/1741143209339655

20. Moldovan, L. (2012). Integration of Strategic Management and Quality Assurance in the Romanian Higher Education, Proceedings of the 8th International Strategic Management Conference: Procedia - Social and Behavioral Sciences,Vol.58, pp. 1458-1465. [Online] Available at: http://www.sciencedirect.com/ science/article/pii/S 1877042812045946 [Accessed 29 December 2013]. http://dx.doi. org/10.1016/j.sbspro.2012.09.1132

21. Morden, T. (2007). Principles of Strategic Management (3rd ed). UK: MPG Books Ltd.

22. Nag, R., Hambrick, D. C., Chen, M. J. (2007). What is strategic management, really? Inductive derivation of a consensus definition of the field, Strategic Management Journal, 28(9), pp. 935955. [Online] Available at: http://onlinelibrary. wiley.com/doi/10.1002/smj.615/pdf [Accessed 3 December 2013].

23. Standards and Guidelines for Quality Assurance in the European Higher Education Area (2005). 
European Association for Quality Assurance in Higher Education, Helsinki, Finland. [Online] Available at: http://www.bologna-bergen2005. no/Docs/00-Main_doc/050221_ENQA_report. pdf [Accessed 11 January 2014].

24. Stoner, J. A. F. (1978). Management. New Jersey: Prentice Hall.

25. Stråhlman, Ch. (ed.) (2012). Quest for Quality for Students: Going Back to Basics, Brussels, February 2012, European Students' Union ESU. [Online] Available at: http://www.creup.es/documentos/esu-publicaciones/ESU-quest-report. pdf [Accessed 10 December 2013].

26. Stukalina, Y. (2008). How to Prepare Students for Productive and Satisfying Careers in the Knowledge-Based Economy: Creating More Efficient Educational Environment, Technological and Economic Development of Economy: Baltic Journal on Sustainability, 14(2), pp. 197-207.

27. Stukalina, Y. (2010/1). Using Quality Management Procedures in Education: Managing the Learner-Centered Educational Environment, Technological and Economic Development of Economy: Baltic Journal on Sustainability, 16(1), pp. 75.-93.

28. Stukalina, Y. (2010/2). The Management of the Integrated Educational Environment Resources: the Factors to be Considered, European Journal of Education, 45(2), pp.345-361. http://dx.doi. org/10.1111/j.1465-3435.2010.01433.x

29. Stukalina, Y. (2010/3). Some Knowledge Strategies Used to Provide Quality Enhancement of the Educational Environment in a Higher Education Institution, Theory for Practice in the Education of Contemporary Society. Zinātniskie raksti un konferences referāti, Riga: RPIVA, pp. 318.-323

30. Stukalina, Y. (2013). Management of the Educational Environment: the Context in which Strategic Decisions are Made, Proceedings of the 9th International Strategic Management Conference; Procedia - Social and Behavioral Sciences, Vol. 99, pp. 1054 - 1062. [Online] Available at: http://www.sciencedirect.com/science/ article/pii/S187704281304024X[Accessed 5 December 2013]. http://dx.doi.org/10.1016/j. sbspro.2013.10.579

31. Tabatoni, P., Barblan, A. (2002). Strategic Management, A Tool of Leadership - Concepts and Paradoxes. Thema, 2, European University Association, pp. 5-11. [Online] Available at: http:// www.eua.be/eua/jsp/en/upload/strategic_manag_uni_institutional_devlpt.1069322397877.pdf [Assessed 10 October 2013].

32. Tabatoni, P. (2002). An Explanatory Glossary, Thema, 2, European University Association, pp. 23-28. [Online] Available at: http://www.eua.be/ eua/jsp/en/upload/strategic_manag_uni_institutional_devlpt.1069322397877.pdf [Accessed 10 October 2013].

33. Tavernier, K. (2005). Relevance of Strategic Management for Universities, Tijdschrifr voor Economie en Management, Vol. L, 5. [Online] Available at: https://lirias.kuleuven. be/bitstream/123456789/120121/1/tem_5_05_ tavernier.pdf [Accessed 20 December 2013].

34. The European Higher Education Area in 2012: Bologna Process Implementation Report, 2012. [Online] Available at: http://www.ehea.info/Uploads/(1)/Bologna\%20Process\%20Implementation\%20Report.pdf [Accessed 7 December 2013].

35. Thompson, A. A., Strickland, A. J. (2003). Strategic Management: Concepts and Cases. USA: McGraw-Hill/Irwin.

36. Watson, D. (2000). Managing Strategy. Buckingham: Open University Press.

The paper submitted: May 9, 2014 Prepared for publication: June 4, 2014

\section{Yulia STUKALINA}

\section{STRATEGINIS AUKŠTOJO MOKSLO INSTITUCIJŲ VALDYMAS}

\section{S a n tra u a}

Šiandien dèl padidejusios konkurencijos tarp universitetų, siekiant pritraukti ir išlaikyti studentus, švietimo vadovai yra priversti peržiūrèti savo strategiją, kurios pagrindinis tikslas nustatyti veiksnius ir rodiklius kuriančius konkurencinị pranašumą.
Mokslineje literatūroje teigiama, jog efektyvios strategijos sukūrimas siekiant organizacinio vystymosi yra vienas iš pagrindinių uždavinių šiuolaikiniams vadovams. Strateginio valdymo teorijos pateikia naujus požiūrius $\mathfrak{i}$ strategijos vystymą aukštojo 
mokslo institucijose. Nors ji ir neišsprendžia visų aktualių klausimų, su kuriais susiduria švietimo vadovai. Dèl šiuolaikinių universitetų specifiškumo aukštesnio lygio vadovams atsiranda vis didesnis poreikis rekomendacijoms apie strategijų kūrimą, siekiant akademinés kompetencijos ir konkurencinio pranašumo. Todèl yra reikalinga išsami tradicinių ir inovatyvių požiūrių analizè, kuri padètų švietimo vadovams strategijos formavimo klausimais. Pagrindinis šio straipsnio tikslas - nustatyti ir aptarti pagrindinius modernaus universiteto strategijos formavimo principus ị vartotojų poreikius orientuoto švietimo kontekste ir skatinti tolesnes diskusijas šia tema. Tyrimo tikslas - atlikti išsamią vidinių veiksnių, kurie sukuria sudètingą mokomąą aplinką aukštojo mokslo institucijoje, analizę. Teigiama, jog reikia kurti ir igyvendinti keletą strategijų, švietimo vadovai turi atskirti korporatyvinio lygio strateginius tikslus nuo funkcinių, konkrečių padalinių strateginių tikslų, kurie susiję su universiteto strateginių sričių plètra ir moksliniais tyrimais. Šiuolaikiniai universitetai, būdami didelès ir sudètingos organizacijos, reikalauja integruoto požiūrio strategijos kūrimo ir igyvendinimo srityse. Aukštojo mokslo institucija apima įvairias integruotas ir tarpusavyje susijusias posistemes. Akademinis universiteto stiprumas yra grindžiamas ịvairiais organizaciniais ištekliais (materialiais, nematerialiais, pusiau materialiais). Taigi, strateginiai tikslai turi būti nustatyti remiantis holistiniu požiūriu - integruotu švietimo aplinkos išteklių valdymu. Strateginiai sprendimai priimami atsižvelgiant $i \mathfrak{i}$ daugybę aplinkybių ir socialinių situacijų. Aukštojo mokslo institucijose yra reikalingos sudètinès, ịvairius organizacijos lygmenis apimančios, ir funkciniuose vienetuose veikiančios, strategijos. Šiame straipsnyje atlikta analizè leidžia autorei daryti išvadą, kad strateginių iniciatyvų igyvendinimas apima akademinès kompetencijos ir konkurencinio pranašumo kūrimą, kuriam pasiekti reikalingi vidiniai švietimo aplinkos ištekliai ir išorinis finansavimas, dèmesị sutelkiant i griežtą bendradarbiavimą organizacijos viduje, siekiant sinergijos visuose funkciniuose padaliniuose. Siekiant šio tikslo sisteminis vertinimas integruotoje švietimo aplinkoje gali būti naudojamas užtikrinti kokybę švietimo sistemoje. Šio straipsnio metodologija yra grindžiama strateginio valdymo mokslinès literatūros apžvalga. Straipsnyje pateikta analizè remiasi autorès profesine patirtimi švietimo valdymo srityje. Autorè tikisi, jog atlikta analizè padès švietimo vadovams patobulinti aukštosios mokyklos strategijų kūrimo ir vystymo procesus. 